\title{
Trapped in mirror-images: The rhetoric of maps in Israel/Palestine
}

\author{
Yair Wallach \\ School of Oriental and African Studies, University of London, Thornhaugh Street, London WC1H OXG, United Kingdom
}

\section{Keywords:}

Maps

Territory

Nation-state

Critical cartography

Israel/Palestine

Performativity

\begin{abstract}
A B S T R A C T
The map of Israel/Palestine has long been used by both Israelis and Palestinians, from their unequal power positions, as a celebrated national symbol. It is virtually the same map, depicting a sliver-shaped land between River Jordan and the Mediterranean, two overlapping homelands in one territory. Thus, a single geo-body appears to contain two antagonistic and asymmetrical nations, locked in a bitter struggle. The article interprets the uncanny mirror-maps of Israel/Palestine by drawing on recent work in critical cartography. One approach has read maps as rhetorical claims for power and over territory; indeed, the mirror-maps of Israel/Palestine are often read as indications of maximalist territorial ambitions and hidden wishes to "wipe the other off the map". However, this article suggests an alternative, de-territorialised reading of political maps as "empty signifiers" of multiple meanings. Following analysis of maps as objects of performance, whose meaning depends on users and contexts, the article emphasises the ritualistic sacralisation of the Israel/Palestine map. Embedded within discourses of memory and history, maps are tools of narrating the nation, often in diasporic contexts, carrying with them vast emotional significance to both peoples. These issues were largely left unaddressed by the territorial paradigm which has dominated scholarship and political negotiations. Moving the discussion of geography beyond narrow territorial claims towards an appreciation of the richness and heterogeneity of space is crucial, yet faces formidable challenges both politically and conceptually.
\end{abstract}

(c) 2011 Elsevier Ltd. All rights reserved.

\section{Introduction}

If one needed a reminder of the criticality of maps to contemporary geo-political discourse, one could be found easily in the controversy around Iranian President Mahmoud Ahmadinejad's 2005 public call to "to wipe Israel off the map". Ahmadinejad's comments were repeatedly cited in global media, often in the context of Iran's nuclear aspirations, as evidence to Iran's wish to destroy Israel. However, as several scholars have pointed out, Ahmadinejad never used the idiom of "wiping off the map", which does not exist in Farsi, but rather spoke of the "occupation regime vanishing from the page of time" (Steele, 2006). And yet the corrected translation failed to register with Western politicians and commentators, who continued to repeat the mistranslation. Regardless of what one thinks of Ahmadinejad's hostile intentions towards Israel, the fact remains that public opinion, especially in the West and in Israel, was captivated by the "wiping off the map" idiom. It seemed obvious - to the point that it required no explanation - that the appearance of Israel on the world's political maps is synonymous with its existence as a state and as a nation. It is this

E-mail address: yw11@soas.ac.uk. very transparency, and the ambiguities it conceals, that this article explores, through the mirror-image maps of Israel and Palestine.

The key issue for this article is the fact that the Israeli and Palestinian homelands are depicted in maps almost identical in shape, consisting of virtually the same territory. Both peoples, inhabiting extremely unequal power positions, celebrate maps as a prominent rhetorical vehicle. These maps depict a sliver-shaped land between the Mediterranean Sea and the River Jordan, delimited by the borders of the British Mandate (1922-1948), giving it its iconic "knife shape", with the blade pointing downwards (Wood, 2010). Palestinians refer to this territory as "Palestine" or "historical Palestine", while Israelis call it "Land of Israel", or "Greater Israel" (the only significant difference is that Israeli maps, unlike Palestinian maps, also include the Golan Heights, occupied from Syria in 1967; yet this addendum does not alter the shape of the map considerably). An ignorant outsider could easily confuse the Israeli and Palestinian maps. Yet Israelis and Palestinians distinguish easily between the maps through visual and textual cues such as legend, place names, and colouring. Much like in other countries, the mirror-maps of Israel and Palestine are "logo-maps" (Anderson, 1991), celebrated national icons, reproduced on a myriad of material objects and contexts from weather forecast maps (Fig. 1) to necklaces (Fig. 2). Instantly-recognisable and everywhere-visible, these maps are a form of "banal nationalism", weaving nationalist 


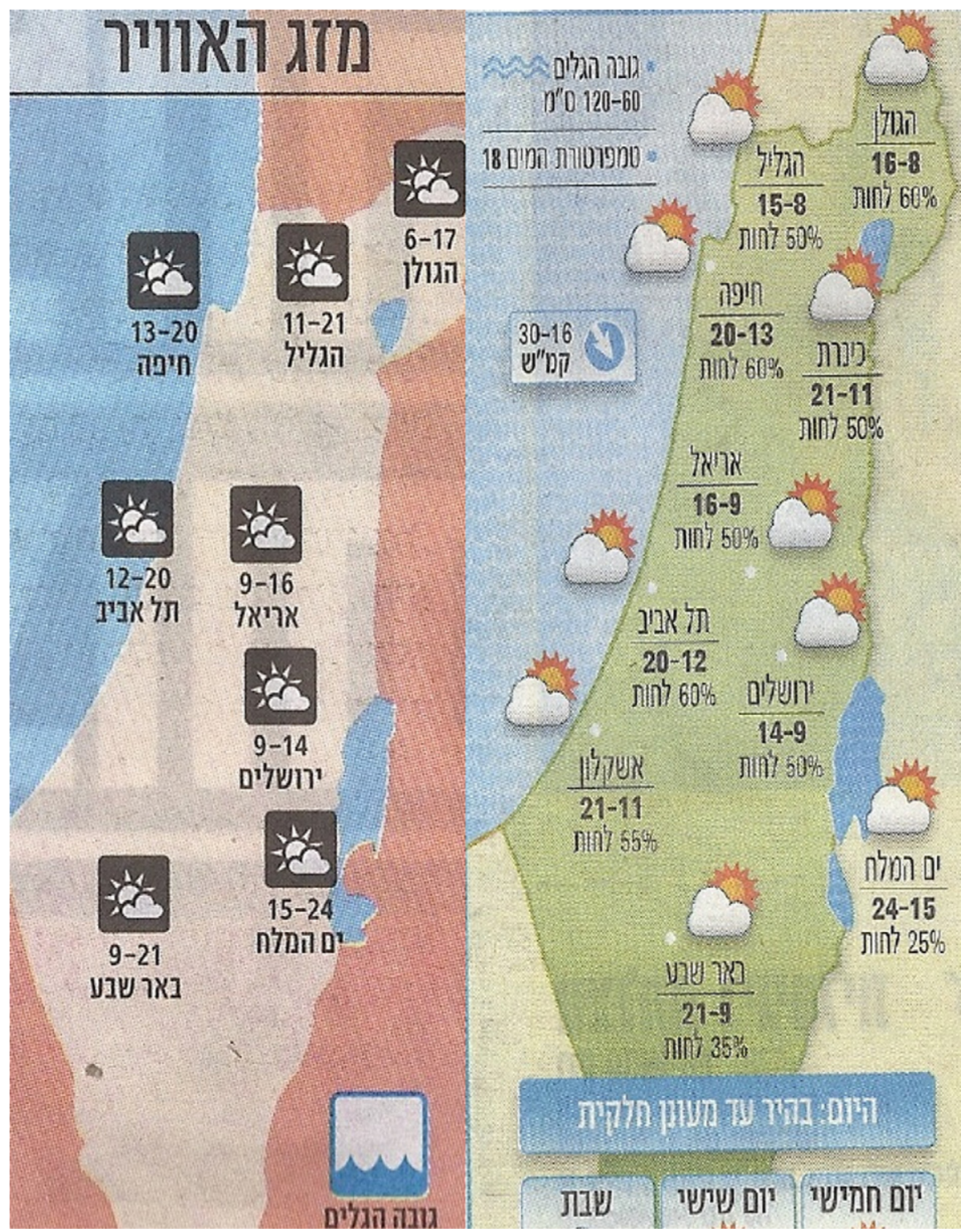

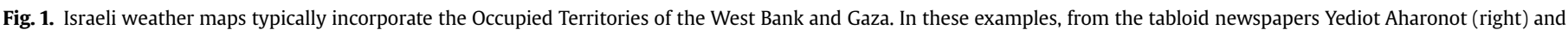
Israel Ha-yom (left), Palestinian cities are omitted from the map, yet the Israeli settlement of Ariel in the West Bank is mentioned by name. February 2011. Author's collection.

discourse into the seemingly unremarkable fabric of everyday life (Billig, 1995). This succinct visual depiction shapes the popular geographical imagination of the nation as a "geo-body", a clearlydemarcated, cohesive and unified organism (Winichakul, 1994). What is unique to the Israel/Palestine conflict, however, is that the same "logo-map" is used by two opposing national projects, and that the same "geo-body" inhabits two nations.

In most Israeli and Palestinian maps the country appears as an integral whole, as either "Israel" or "Palestine". This, however, does not reflect the international consensus in legal and geo-political terms. The entire territory is under the effective rule of Israel, but it is composed of two parts: Israel "proper", in its pre-1967 borders, and the West Bank and Gaza, under Israeli military occupation since 1967. The Palestinian Authority, established in 1993, enjoys limited autonomy in parts of these occupied territories. Some Israeli and Palestinian maps indicate these subdivisions in broken lines, small lettering or faded colours, yet overwhelmingly, they portray the country as a single unit, clearly distinct from neighbouring countries. In demographic terms, the population between the River and the Sea is divided almost equally between Israeli Jews and Arab Palestinians, yet this again would be difficult to discern by looking at these maps, which highlight either the Jewish-Israeli or Arab Palestinian character of the country, through the nomenclature and the choice of towns and villages shown on the map (Peled-Elhanan, 2008).

Clearly, this would hardly be the first example of political maps that do not reflect "reality". There are numerous examples of modern states who portrayed their territories as larger than they actually were, from the late Ottoman Empire (Fortna, 2005) to Ecuador (Radcliffe \& Westwood, 1996). Similarly, the Palestinians are not the first group to challenge the prevailing geo-political order using alternative maps. Indigenous peoples in Canada (Sparke, 2005), West Papua (Webster, 2001) and Basque separatists (Mohr, 2006) are just few examples among many, where "countermapping" is employed as a tool of resistance. In all these examples, 


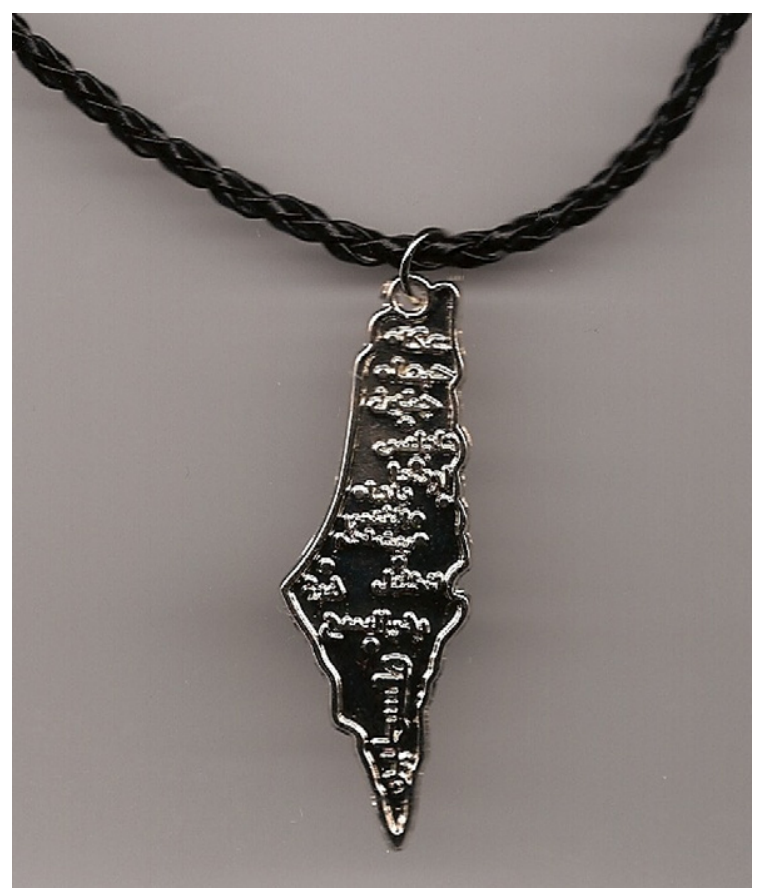

Fig. 2. Necklace with the Palestine map, with names of Arab cities. Jewish cities, most notably Tel Aviv, do not appear on the map. Author's collection.

however, the maps and counter-maps differ significantly and visibly from each other, and refer to different territories. Basque maps project a map of "the seven provinces", torn from Spain and France, to depict the Basque homeland as a single unit; the map of Tamil separatists claims coastal areas of northern Sri Lanka as "Tamil Ealam", differing considerably from the official map of the island as a single state; Irish Republican maps envisage the entire island as a single territory with no political divisions, while Loyalists celebrate maps of Northern Ireland as a British region, with the rest of Ireland often missing altogether (Figs. 3 and 4). In all these cases, nationalist groups offer an alternative political map, that does not resemble the official maps in place. Separatist or irredentist aspirations could, at least theoretically, be accommodated with the redrawing of internal and external borders, creating larger countries, autonomous regions, or break-away nation-states. Indeed, as several scholars have pointed out, counter-mapping practices of indigenous peoples reify and confirm the territorial logic of the nation-state (Sparke, 2005). Yet the Israel/Palestine map, I argue, poses a greater challenge to the rhetoric of maps and the geo-political order of territorial nation-states, because the same territorial framework is used as a basis of two different national projects. The totalisations inherent to these maps, the fact that the two refer to virtually the same territory, makes it difficult to imagine how these differences can be reconciled through territorial compromise.

In his work on geography school textbooks, Anssi Paasi (1999) has argued that in territorial communities, the view of the Other

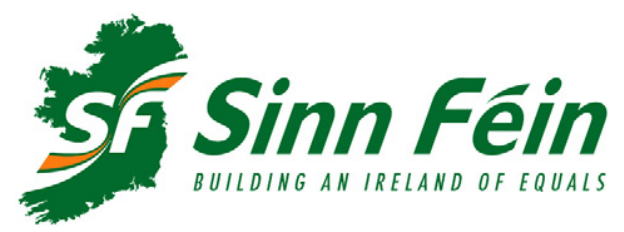

Fig. 3. Sin Fein logo, envisioning a united Ireland. Courtesy of Sin Fein.

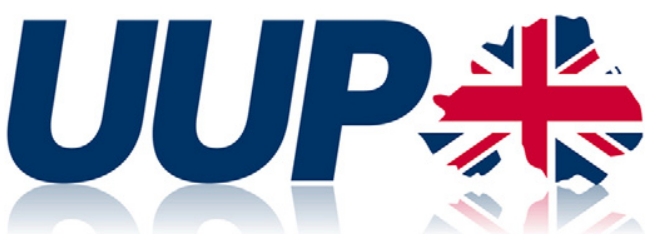

Fig. 4. Ulster Unionists Party logo, depicting Northern Ireland as a British territory, disconnected from the rest of Ireland. Courtesy of UUP.

(and self) are constructed through practices of socio-spatial distinction between us and them. However, most Israeli and Palestinian maps give no place to their Other, who is either ignored altogether or incorporated as part of one's own territory. The adversary is given no room, despite the fact that both sides are all too aware of the existence of the other. Given that the two sides are locked in a dialectical struggle that has defined much of their national projects for the past century, this denial can be seen as highly destabilising. The inability/unwillingness to point to a border between us and them, not only denies the legitimacy of the other: it also undermines the stability and legitimacy of "us". What emerges is a picture of a geographic schizophrenia: two adversary and asymmetrical nation-selves inhabiting a single geo-body.

The mirror-image aspect of Israeli and Palestinian cartographies has received little mention in the literature, despite avid interest in the country's mapping. The historiography has largely focussed on the use of maps by colonial powers and later Israel to legitimate and advance their control over this territory (Benvenisti, 2000; Gavish, 2005; Moscrop, 2000; for an overview see Wood, 2010). These studies support the view of maps as tools and representations of hegemonic power (Harley, 1989). Some attention has been given to artistic subversions of mapping practices to challenge Israeli discourses (Rogoff, 2000; Wood, 2010). Palestinian maps have received far less attention, despite growing interest in maps of resistance (Mogel \& Bhagat, 2008). Denis Wood has discussed the use of the Israel/Palestine map by both national movements to promote nationalist reactionary visions. Wood describes the Palestinian map as a "counter-map", a response to Zionist-Israeli maps that erased the Arab character of Palestine, or in his words, an example of cartographic "tit-for-tat" (Wood, 2010: 246). While not without validity, this observation fails to capture the resonance of the map as symbol of Palestinians' identity and nationhood. Furthermore, the antagonistic duality of the Palestine/Israel map deserves closer attention, as this case study presents both an opportunity and a challenge to the critical study of maps.

Critical cartography has emerged in recent decades as a vigorous debate on the meaning of maps and mappings. This article does not seek to summarise all the developments in this rich field; for excellent overviews see Crampton and Krygier (2006), Dodge, Kitchin, and Perkins (2009). My contribution focuses on what I see as the inherent tension between two main trajectories in this intellectual arena. The first trajectory, relying primarily on a semiotic tradition, reads maps as statements and propositions, emphasising their role in the struggle for power and for domination over territory (Black, 1997; Harley, 1989; Wood, 2010; Wood \& Fels, 2008). This, as I discuss below, is indeed how maps have often been read in the Israel/Palestine conflict: as claims and counter-claims for the same territory. However, reading maps only as territorial claims is reductive, and misses their greater significance. In this article I suggest a de-territorialised reading of the political map as an "empty signifier" which is at the heart of the nationalist discourse. The semiotic term "empty signifiers" refers to a signifier (often non-linguistic) whose referent is vague and highly variable, and whose meaning differs widely according to interpretation. 
In Laclau's work, however, the "empty signifier" is signalled out as the crucial element that sits at the centre of discourse and holds it together (Laclau, 2007). It is exactly the lack of concrete content that allows the empty signifier to bind different elements into a discursive formation. The Israel/Palestine map acts in such a way: its vast resonance and emotional appeal cannot be pinned down and translated into a clear definition, yet nevertheless it creates the terms of reference to arrange diverse and often contradictory agendas within Palestinian and Israeli discourses. As a privileged symbol of the nation, the map plays a role in discourses of cultural memory, history and identity; these discourses hinge on geographical notions of the homeland, but they are not strictly territorial. The meaning of the map is therefore not inherent but rather dependent on its discursive context. My analysis draws on recent contributions which have highlighted the dynamic operation of map-use, moving away from considering maps as stable objects with fixed meanings. This intellectual trajectory examines maps as inscriptions (Pickles, 2004), practices (Perkins, 2008), narratives (Pearce, 2008), performances (del Casino \& Hanna, 2005), and more generally, as "mappings" rather than fixed maps (Kitchin \& Dodge, 2007). At the same time, there has been an emphasis on the affective power of maps (Aitken and Craine, 2006; Kwan, 2007). Maps are not simply rational statements to be interpreted through a logical calculus, but rather are material objects invested with emotions, love and pain. Relying on these insights, this article examines the performative use of maps in Zionist-Israeli and Arab Palestinian contexts, from the early twentieth century to the present day. My examples highlight the employment of maps in education, which are particularly influential to narrate the nation and shaping socio-spatial consciousness (Paasi, 1996, 1999). I also discuss maps on memorials, stamps, weather reports, and other objects.

The framework of peace negotiations since the 1990s has sought to resolve the Israeli-Palestinian conflict through territorial partition and the creation of a Palestinian state - so far unsuccessfully. In this context, Israel/Palestine mirror-maps have been read as maximalist and irreconcilable territorial claims. In this article, however, I argue that the issue - as represented in Israeli/Palestinian mapping practices - is not maximalist territorial ambitions of the two sides, but rather the constraints of the territorial framework itself. It is a host of non-territorial issues expressed through map-use - most notably historical narrative, cultural memory and the Palestinian "Right of Return" - which have been left unaddressed by negotiations, and cast doubt on the viability of territorial partition as a "solution". Finally, in the face of the seeming contradictions between these two totalising maps, I return to the insights of critical scholarship in search of possible analytical routes out of the deadlock. Scholars of Israel/Palestine are indeed eschewing simplistic demarcations of us/them to emphasise the rich palimpsestic quality of space. Moving the discussion of geography beyond narrow claims to territorial sovereignty is crucial, and yet faces formidable challenges both politically and conceptually.

\section{The clash of maps: cartography as claim}

Modern cartography has been an important tool in staking and sustaining territorial claims, especially in contested frontier areas (Black, 1997; Monmonier, 1996). Reading maps as "claims" implies a semiotic approach, that considers maps as a series of statements, which can be interpreted through codes. Scholars who follow this approach see maps as propositions promoted by those in power or those striving for power (Wood \& Fels, 2008). According to Wood and Fels, the cartographic proposition is a complex linkage of conditions, processes and behaviours, but they are all conjoined through territory: "the map is a vehicle for creating and conveying authority about, and ultimately over, territory" (Wood \& Fels, 2008: 27).

Indeed, in the Palestine/Israel conflict, maps have been repeatedly presented and read as claims for factuality. While divided bitterly on questions of history and justice, Israelis and Palestinians seem in agreement on the "objectivity" of maps and their power to express factual truth. A pro-Palestinian website states that "the maps tell the real story [...] Israel is the aggressor [...] a nation eager to conquer lands which do not belong to it" (whatreallyhappened.com). On the other side of the debate, Israel's Ministry of Foreign Affairs' website offers maps providing "factual and background material" to counter the "myths, slogans, prejudices" used by Israel's critics (Israel Ministry of Foreign Affairs, 2008). Mirror-maps of Israel and Palestine have been in use for many decades, and yet on occasion these maps are suddenly "discovered" amid outrage and outcry. Palestinians or Israelis are then accused of espousing extreme "all-or-nothing" territorial ambitions, and denying the other's right to exist. Two recent controversies demonstrate this point.

As of the early 2000s, several Israeli research groups published reports accusing Palestinian textbooks of incitement against Israel (Pina, 2005). The issue of maps was a primary focus to these allegations. Maps in Palestinian textbooks, up until 2007, did not include any reference to Israel or to Jewish-Israeli cities, while many places within Israel such as Haifa and the Galilee were described as located in Palestine. The omission of Israel from the maps was seen as indicative of the Palestinian national agenda: "a continuing denial of the State of Israel's right to exist [...] incitement against the State of Israel and the Zionist movement [...] the Palestinian Education Ministry educates its students to hate Israel and to aspire for Israel's disappearance from the region" (Meridor, 2006). Subsequent studies of Palestinian textbooks by other, nonpartisan scholars questioned the methodology and findings of the original reports (Brown, 2001), yet all noted the absence of Israel from Palestinian maps, and the tendency of geography textbooks to avoid a clear definition of Palestinian borders.

The controversy attracted international media attention during the second "Al-Aqsa" Intifada (2000-2005), one of the most violent periods of the Israeli-Palestinian conflict. Israeli research groups were keen to expose, through the Palestinian curriculum, the culpability of the Palestinian Authority for this violence and the insincere nature of Palestinian commitment to the peace process. These allegations had an impact on policy makers, especially in the USA, and the authors of these reports were able enlist US Senator Hillary Clinton for their cause (PMW, 2007). The issue of Palestinian "incitement" in the education system continues to be raised routinely by Israeli politicians.

The omission of Israel from Palestinian maps is countered by a similar failure of Israeli maps to mark the Palestinian territories under military occupation. Israeli maps have not received similar scrutiny, certainly not from the US Congress. And yet in 2009 an Israeli tourism campaign in London Underground stations, featuring large maps, triggered strong complaints from pro-Palestinian activists claiming that the maps were "wiping Palestine off the map" - so much that the posters were eventually removed (BBC, 2009). Israel, as it was portrayed on the posters, included the West Bank and Gaza, and the former 1967 borders were marked with an almost invisible broken line. These "insidious" maps, according to the UK Palestine Solidarity Campaign, represented a "disingenuous attempt to remove the Palestinians from the public mind, and create a false impression about what constitutes Israel". Ironically, the Palestine Solidarity Campaign uses as its symbol the map of Palestine, with no reference to Israel (www.palestinecampaign.com). Similar protests were made by Palestinian journalist Daoud Kuttab (Kuttab, 2010) regarding maps used in 2010 by the Israeli tourism ministry. 
What is most striking about these tourism maps was the inclusion of the Gaza Strip as an unambiguous part of Israel. Ever since the 2005 withdrawal of Israeli troops and settlers from the Gaza Strip, Israel has officially claimed that its military occupation of Gaza was over; that it had no responsibility for and control over that territory. International human rights organisations have rejected this claim, pointing out that Israel retained indirect control over Gaza's by controlling its borders. As of 2009 it was virtually impossible for foreign humanitarian workers - let alone tourists to enter Gaza due to the Israeli blockade on the Strip (Palestine Solidarity Campaign, 2009). Why, then, did Israeli maps continue to include Gaza, refuting Israel's international public relations efforts? I shall return to this question later.

In both these examples, maps are read as territorial propositions. By portraying the entire territory as a single unit, Israelis are expressing their claim to maintain rule over the country, while Palestinians indicate their wishes to achieve such control. In this interpretation, both sides leave no room for a sovereign other, and seem to reject the idea of partitioning the country. "This geographical symbolism [of Israeli maps] is incompatible with the two-state solution", argued Kuttab (2010). The maps are read as a Freudian slip, going beyond deceptions of media rhetoric, and revealing what Israelis and Palestinians "really want". The true intentions of both sides can be deciphered through the simple code of mapping. Alternatively, the maps are read as propaganda: a conscious attempt to promote an ideological vision for public consumption through false claims. Propaganda maps have been studied in numerous contexts, such as official maps of India and Pakistan that "continue to deny political reality" by depicting the entire disputed region of Kashmir under their control (Monmonier, 1996: 91). And yet the distinction between "propaganda maps" and "true maps" has been questioned in critical cartography (Harley, 1989) exactly because all maps, as schematic representations of space, lie, in one way or another.

A more fundamental question, however, is whether maps should be reduced to territorial claims. In his seminal work on map as "geobody", Thongchai Winichakul (1994) argued that the power of maps stems from their inherent potential for multiple signification. When a map becomes a metaphor for the nation, it no longer necessarily refers to the territoriality of that nation; it can generate values and meanings which have nothing to do with territoriality at all. Diverse ideological trajectories and notions of identity are projected onto the map, which becomes, in Laclau's terminlology, a key "empty signifier" (Laclau, 2007), binding the discourses of nationhood together. As I shall argue, it is exactly their ability to express aspects of history, cultural memory and identity - which have a spatial anchoring, but are not strictly about territory - that have made maps so ubiquitous in both Israeli and Palestine cultures.

In her work on maps-as-narratives, Pearce (2008) has argued that it is experience and memory which give maps their emotional power to turn space into unique place. Her approach differs from a semiotic reading of the map as a series of facts and propositions, as it emphasises the plurality of narratives, and their evocative rather than argumentative - qualities. The reading of any mapstory is a performative act, whose meaning depends on context and readers (del Casino \& Hanna, 2005). Rather than fixed and stable narratives, maps present opportunities of narrating leading to many possible stories. Significantly, the narrating of Israel/ Palestine maps occurs often in a de-territorialised context, in international media, the internet, and in diasporic Jewish and Palestinian communities. In these removed contexts, the map's reference to actual territory is abstracted further.

We should also consider the psychological effect of maps. Israeli and Palestinian hostile reaction to the other's map could be explained not only because of the claims it supposedly represents, but also because of its unsettling effect. There is something deeply uncanny about the juxtaposition of these mirror-maps. Famously, Freud's prime example of the uncanny was the "double", that is, cases of repetition and replication, which create strong uneasiness (Freud, 2003). Like mirror-images, instances of the double are both identical and opposing at the same time. The doubled instance is the discovery of what was supposed to remain hidden and concealed. In Palestine/Israel, it is the other's presence and historical narrative which have been suppressed, rejected, and blocked out, but now return in reified and objective visual form of the map. It is useful to recall that the German term for uncanny is unheimlich, literally "unhomely". Being a stranger in one's home is perhaps the most uncanny and disorientating experience that can be imagined. The simultaneous feeling of familiarity on the one hand, and strangeness on the other, creates a strong cognitive dissonance and emotional discomfort. Faced with the other's map, Israelis and Palestinians recognise it instantly as home(land), and yet it is a cartographic home in which they have no place. For Palestinians, this displacement is real, physically and politically, while for Israelis, it is on a symbolic level, a reminder that their control over the country remains contentious and illegitimate in the eyes of many.

To appreciate the operation of maps, and their psychological, affective and narrative significance, it is necessary to move away from seeing them as rational statements (true or false), and to examine maps as processes, practices, and performances. The next two sections provide a short history of the performative use of maps in both Israeli and Palestinian societies, emphasising their ritualistic and sacralised role. Following Juliet Fall's work on borders (2010), I believe that fetishisation is among the key operations of mapping in Israel/Palestine.

\section{Israeli maps}

The Zionist movement was early to use the map as a propaganda device and a national symbol. From the beginning of the British Mandate in the early 1920s, the map of Palestine, or in Hebrew "Land of Israel", featured on Zionist posters, stamps and symbols. These maps were revered as sacred objects, in ritual practices that invested them with a semi-religious aura. The most famous example was the map painted on a Zionist donation box, known as the "Blue Box" map (Fig. 5). These donation boxes were distributed by the Jewish National Fund (JNF), the main Zionist landpurchasing organisation, which played a pivotal role as a Zionist propaganda agent (Bar-Gal, 2003). The map highlighted the territories purchased by the JNF, and the donated pennies were to serve for Jewish "land redemption". The box was painted in the national Zionist colours of blue and white, originally derived from the colours of the Jewish prayer shawl. Millions of Blue Boxes were distributed in Palestine and the Jewish Diaspora, and especially in Jewish education institutions. Bar Gal argues that the actual fundraising value of the boxes was limited, yet the "Blue Box" was instrumental to promote the idea of "land redemption" and in making the map an anchor of Zionist sentiment and desires. The JNF encouraged the use of the Blue Box as ritual objects of sort, placed in special "JNF corners" in classrooms (Fig. 6), and venerated in monthly ceremonies in which the box was emptied of its coins. Dropping coins into the box and emptying it were performances of identity through which Jewish boys and girls, far beyond Palestine, developed an attachment to the map, representing their participation in the national project. These rituals and the emotional investment in the map transformed it into something of a sacred object. From visual description of geography, it became an abstract icon of Jewish salvation.

An important aspect of Zionist-Israeli maps has been the rewriting of the landscape into historical and geographical narratives 


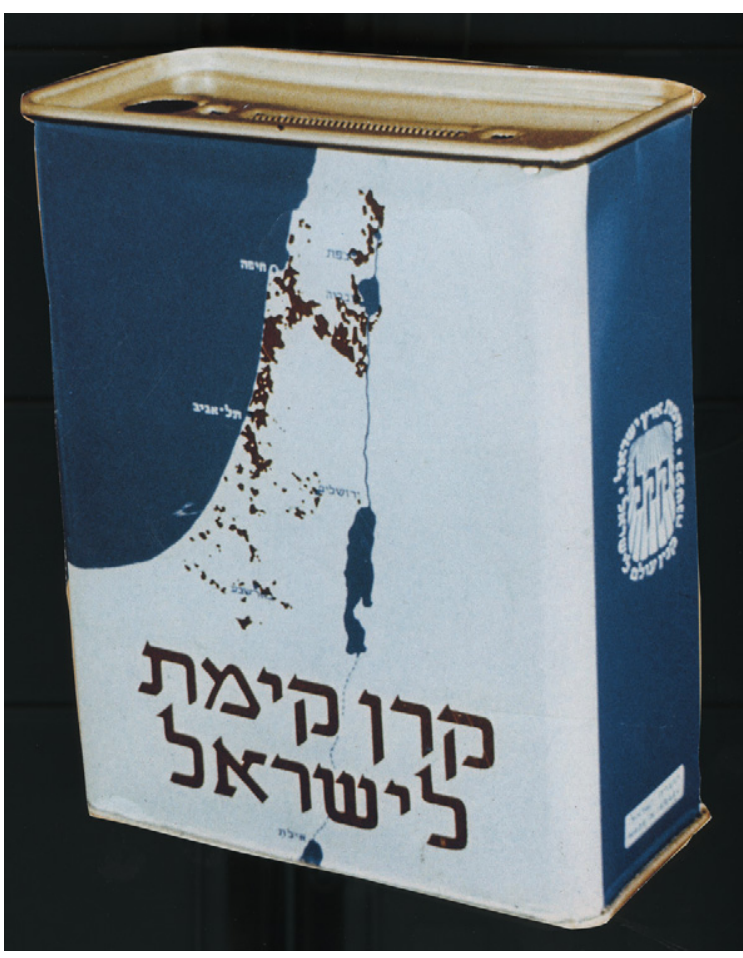

Fig. 5. JNF box, manufactured in 1934. Courtesy: KKL-JNF photo archive.

that provided depth to modern Jewish national identity. The act of narrating always involves a selective approach to events, places and historical facts; the narrating of the map highlights a certain story about the landscape, while suppressing other stories. The double project of rewriting and erasing was examined in Meron Benvenisti's (2000) illuminating study of the 1950s Israeli campaign to rename the Negev region. A committee of learned scholars was formed to assign Hebrew names to the geographical sites and features of the Negev region, choosing biblical, pseudo-biblical and historical-sounding names, with limited scientific justification. The Arab character of the landscape was removed on a symbolic level: of original 553 Arab names, only 8 were left unchanged, as part of the delegitimisation of Arab rights over the country (see also Peled-Elhanan, 2008). The new

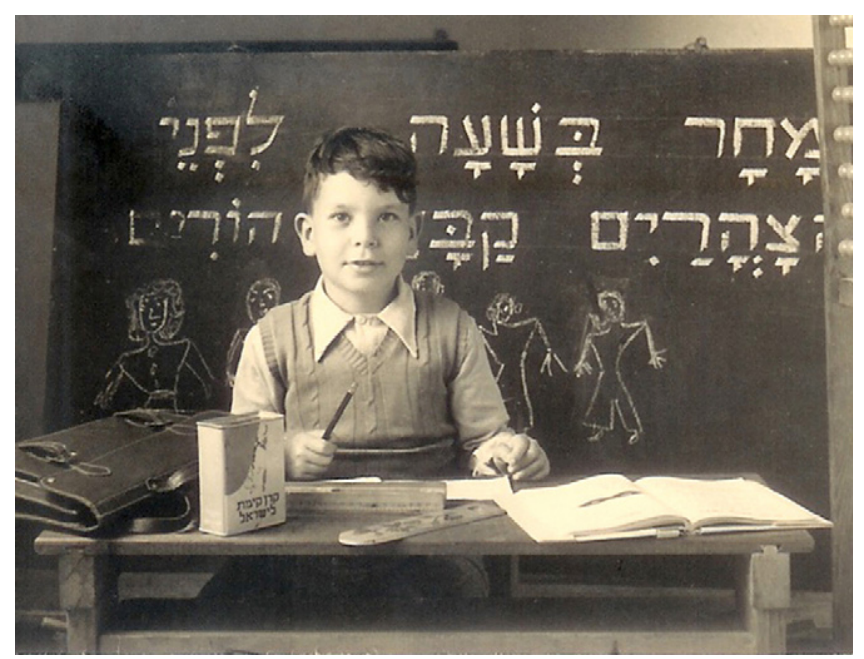

Fig. 6. JNF donation box in a Israeli classroom, 1954. Tsofit archive via the PikiWiki Israel free image collection project (public domain).
Hebrew map created a sense that the country had an uninterrupted Jewish history, going back to the days of the Bible. This historical depth strengthened Zionist claims over the territory, and encouraged a sense of proprietorship among Jews over a land to which most of them had only arrived recently. Noga Kadman's study on depopulated Palestinian villages in Israeli geographical awareness has shown that the erasure of these villages demanded a sustained effort in signposting, maps, books, newspapers and the physical reshaping of the landscape. In multiple sites and moments of narrating, the Hebrew map has been written into the landscape by official agencies and ordinary map-users, while Palestinian sites were erased or renamed (Kadman, 2008).

One interesting aspect of Zionist-Israeli maps has been their ambiguity on the question of borders. To serve as a national logo, and to represent the "geo-body" of the nation, the homeland has to be delineated clearly, and its borders highlighted and sanctified. Borders are at the heart of national identity, as they define the territorial separation between the nation and its Others (Paasi, 1999). Yet most early Zionist maps, such as the "Blue Box" map, did not show political borders at all, leaving undefined the exact territorial limits of the Land of Israel (Bar-Gal, 2003); an interesting exception, which cannot be discussed in detail here, is the minority "Revisionist" movement, right-wing Zionists who chose as their symbol a political map of Palestine inclusive of Transjordan as a single political unit. However the Revisionist map, with its highlighted borders, stood out against a plethora of mainstream Zionist maps with no borders at all. The omission of borders was a deliberate choice, which to some degree reflected pragmatism, as it allowed Zionist leadership to accept proposals for a Jewish state in part of Palestine, first in 1937 and later in 1947. At the same time, it also reflected the expansionary impulse of the Zionist movement, and the desires to extend into territories in Transjordan, Lebanon and Sinai. Even after the establishment of Israel, geography textbooks remained ambiguous on the question of the country's borders, always presenting borders which were wider than the actual extent of Jewish settlement (Bar-Gal, 1991). After 1967, school maps were quickly redrawn to incorporate the new areas occupied by Israel, and the status of the occupied territories was rarely discussed.

However, Mandatory Palestine remains the core territorial meaning of the "Land of Israel" in Israeli geographical imagination (Wood, 2010). A simple Google search in Hebrew for images of "map of Israel" easily proves this point: as of January 2011 virtually all the maps that are retrieved depict Israel as extending to the whole length of Mandatory Palestine. These maps include a map of the National Israel hiking trail; a map of the Israeli chiropractor association; maps of the Israel 60th anniversary celebrations; maps of the best Israeli Humus restaurants; maps of the Israeli Survey department; and practically all the weather forecast maps used by Israeli newspapers (Fig. 1).

If maps are seen as rhetorical representations of power (Harley, 1989), Zionist-Israeli maps could be read as instruments of colonisation, as argued by Edward Said (1994). Israeli maps are ideological constructs, seeking to legitimate the Zionist project while hiding and denying the ongoing dispossession of Palestinians. Such a reading is certainly valid, yet it is also reductive. Viewing maps merely as a tool of power misses the dialectical process in which cartographic visual rhetoric has shaped geographical perceptions and political horizons (Biggs, 1999). It ignores the affective quality of maps and their performative role. After nearly a century of use by the Zionist movement as icons of nation-building, maps of the "Land of Israel" acquired vast emotional appeal in popular consciousness.

The map has a visual, tactile and real presence in Israeli everyday life, achieved through myriad instances of inscription. 
A recent exhibition in the Israel Museum in Jerusalem, "On the Map", explored the use of the map as a national icon in Israeli visual culture, celebrating the fact that Israelis can draw this shape "even with one's eyes closed" (Granot \& Grossman, 2008). The nation's geo-body has been internalised and is automatically inscribed in bodily gestures.

Israeli novelist Orly Castel-Bloom has given the most memorable literary expression of the constant inscription of the map in the Israeli psyche, an operation charged with violence and desire. In her novel Dolly City, nationalist mapping becomes pathological obsession as a mother makes incisions on the back of her adopted son in the shape of the country's map:

I took a knife and began cutting here and there [...] Drops of blood began welling up in the river beds cutting across the country. The sight of the map of the Land of Israel amateurishly sketched on my son's back gave me a frisson of delight [...] My baby screamed in pain but I stood firm [...] I contemplated the carved up back: it was the map of the Land of Israel; nobody could mistake it. (Castel-Bloom, 1997: 44)

Like elsewhere in Castel-Bloom's work, Israeli ambivalent fascination with borders assumes delusional proportions, leading ultimately to self destruction (Starr, 2000). The territorialisation of the homeland and national identity involves the inscription of the body through victimisation and aggression, and the violence inherent to this process is directed inwards as much as it is directed outwards. The Arab Other, who is almost never actually encountered in the novel, is nonetheless always feared and anticipated, fuelling the paranoid construction-mutilation of the geo/body.

Perhaps the best proof of the performative significance of Israel's map is its continuous inclusion of Gaza even after the Israeli pullout from the Strip in 2005. As already mentioned, Israeli officials have spent considerable efforts insisting that Israel no longer occupies the Gaza Strip. It is almost impossible to find Israelis advocating the re-occupation of the Strip, even in the Israeli right wing. Nevertheless, the image of the Gaza as part of the "Land of Israel" geo-body is entrenched within public imagination, after being practiced and performed through manifold inscription acts. Albeit feared and detested by most Israelis, Gaza remains a part of their mental homeland, which explains not only its inclusion on maps but also the reluctance to relinquish Israel's indirect control over the Strip.

Israeli maps can be seen as statements; but I believe these are not simply propositions and claims, but rather performative utterances, which are about identity, cultural memory and history as much as they are about territory. As icons of Jewish land redemption and mythical rebirth, the maps are utopian statements, corresponding to the open-ended character of the Zionist project. Embedded in the map are unresolved non-territorial issues central to the discourse of Israeli nationalism, most notably Israel's relationships with the Palestinian people and the Jewish Diaspora.

\section{Palestinian maps}

The history of Palestinian maps and mapping still awaits serious research, and yet several observations can be offered here. Arab Palestinian nationalists employed the map of Palestine as a prominent symbol as early as the 1930s. The map featured on several sets of unofficial postage stamps that were printed as a means of fundraising and distributed in Palestine. One set of stamps was printed in Jaffa in 1938, during the Arab Revolt (1936-1939), a full-scale Arab Palestinian uprising against British rule and Zionist colonisation (Shaath \& Mikdashi, 1981). The stamp shows a map of Palestine titled in English and Arabic "Palestine for the Arabs", superimposed by the Dome of the Rock and the Holy
Sepulchre. The image of the two holiest sites to Islam and Christianity in Palestine was significant as it facilitated the sacralisation of the map, and invested it with a religious aura. The juxtaposition of Christian and Muslim symbols was a prominent motif in Arab Palestinian nationalism, expressing solidarity beyond sectarian divisions (Sorek, 2004). These Arab maps, like Zionist ones, did not display political borders of Mandatory Palestine. They included areas east of the river Jordan, outside Palestine's territorial boundaries, while most of Palestine's southern Naqab region was not shown. As of the late 1930s Arab nationalists did not see themselves committed to the geo-political framework of the Palestine Mandate and to its borders, which, were originally drawn by British and French Colonial officials, very much against the wishes of the Arab Palestinian community (Doumani, 2007).

The nationalist Palestinian geography that was taking shape during the Mandate, crystallised in a shock effect after the trauma of the 1948 war, known in Arabic as the Nakba ("Catastrophe"). Most of Mandatory Palestine came under Israeli rule, and hundreds of thousands were displaced from their villages and towns, settling in refugee camps in Egypt, Jordan, and Lebanon. The pre-1948 political framework of the national movement was shattered; the political freedoms of Palestinians, wherever they lived, were severely limited; and most difficult, their very collective existence as a people was denied, as the name Palestine disappeared from maps and dictionaries (Sanbar, 2001).

Against this background of displacement, denial, fragmentation and political dismemberment, the Palestinian national movement was reborn as a new generation attempted to come to terms with the 1948 trauma. Their mission was to make refugees into a modern nation, through political activism and armed struggle (Sayigh, 1997). A nation, as Winichakul has argued, requires a geo-body, a clear geographical shape to which it can refer, which often emerges following national trauma and loss of territory (Radcliffe \& Westwood, 1996; Winichakul, 1994). The map of Mandatory Palestine was the Palestinian geo-body, acting as a symbol of Palestinians' unity and independent standing as a nation. As of the early 1960s, the map appeared in Palestinian visual art (Tibawi, 1963) and on Arab stamps, issued to support the Palestinian cause (Fig. 7) (Wolinetz, 1975). All major Palestinian political organisations, from the secular Fatah, through leftist Popular Front, to Islamist Hamas, incorporated the map of Mandatory Palestine into their logos, stationery, and posters. Against the Israeli denial of

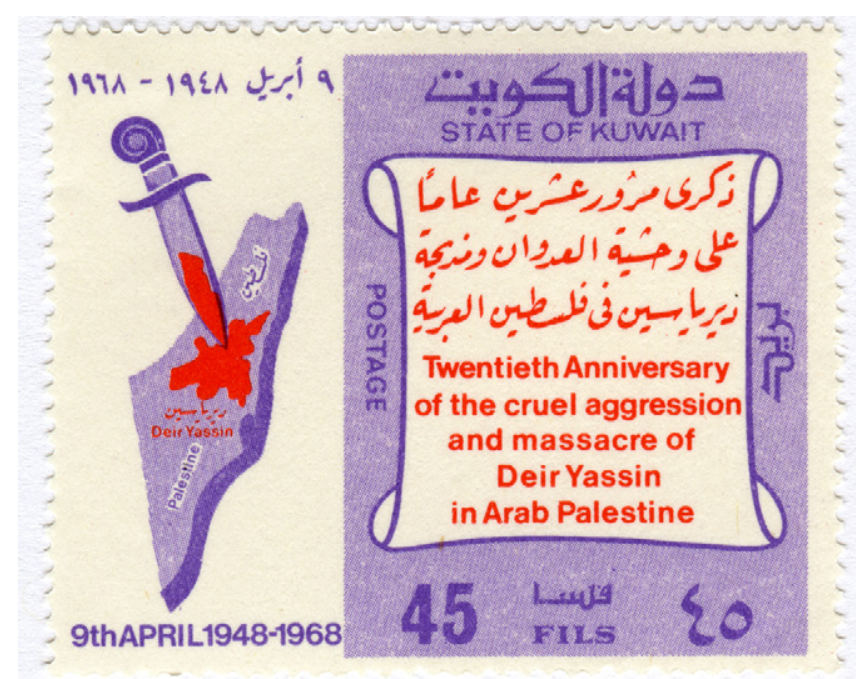

Fig. 7. 1968 Palestine commemoration stamp, issued by Kuwait. Courtesy: Mr. Joseph Morris, USA. 
Palestinian existence and history, and Arab states' attempts to subordinate Palestinian identity to their purposes, the map articulated in clear visual terms the geographic integrity of Palestine as a single unit and a homeland. The 1948 war tore apart communities, regions and families, and threw them into refugee camps in new surroundings; the map called upon them to transcend their regional differences and adopt a single national identity, united by their common loss.

In Palestinian visual culture today, the map is among the most recognisable and celebrated emblems, often featuring alongside the Palestinian flag and the Dome of the Rock in Jerusalem. As Adam Ramadan's (2009) study of refugee camps in Lebanon has shown, these three ubiquitous emblems, the map, the flag and the Dome, create the Palestinian symbolic landscape, and they are used to write nationalism into everyday surroundings. The map is displayed prominently in streets and public spaces, on posters, graffiti and wall paintings. It is a marker of Palestinian individual identity: worn on necklaces (Fig. 2) or on T-shirts, it is also available in various digital forms as "wallpaper" for cellular phones. The Palestinian leader, Yasser Arafat, famously used to shape his kuffiya (headgear) whenever time allowed, to resemble the map of Palestine (Aburish, 1998). The map of Palestine is not simply an abstract symbol: its presence is performed in visual, material and tactile ways.

The map is an especially prominent motif in Palestinian commemoration, contributing to the sacralisation of Palestinian cartography. Memorials for Palestinian martyrs, who were killed in the conflict with Israel, often feature the map. In a Kuwaiti stamp, commemorating the Deir Yassin massacre (committed in 1948 by Zionist forces against a village near Jerusalem), the map of Palestine is stabbed with a dagger (Fig. 7); the homeland becomes the prime victim of the massacre. The map regularly appears in Palestinian commemoration sites, from officiallysponsored monuments to grassroots commemoration plaques, erected by families and friends. Palestinian families who lost their children in the conflict often produce their own commemoration portraits, with the photograph of the son or daughter juxtaposed with emblematic nationalist symbols, such as the map of Palestine. Political sociologist Laleh Khalili (2007), who has observed this commemorative practice in refugee camps in Lebanon, notes that such photos - displayed in the private or public realm - serve as crucial tools for political and armed mobilisations, and are performed by serving as opening points of narratives and conversations. In these posters and monuments, the nation's geo-body is connected to the bodies of the fallen, often literally as the martyr's image or name are superimposed over the map. This visceral connection is highly affective. The emotions roused by the image of the martyrs - from grief and veneration to fury and determination - and also invested in the map; while the map, as a representation of the nation, confirms the place of the martyrs within a sacred nationalist pantheon.

But the map does not only commemorate Palestinian martyrs: it also commemorates the 1948 loss of Palestine, and alludes to the hope for Palestinian Return. Already in the 1950s, school maps used in refugee schools were overprinted with captions "verily we are returning" (Tibawi, 1963). In various representations, the map is accompanied with images of refugees awaiting to return to Palestine, or with their symbolic keys of the lost homes (Fig. 8). The map acts as a visual embodiment of the Palestinian "Right of Return", which is the very basis of Palestinian nationalism, and the centrepiece of Palestinian political mythology (Bowker, 2003; Peretz, 1993). What often escapes commentators is that the "Right of Return" transcends the refugees' demand to return to their ancestral villages and towns; it also includes a return to geography and history books; a return to international recognition

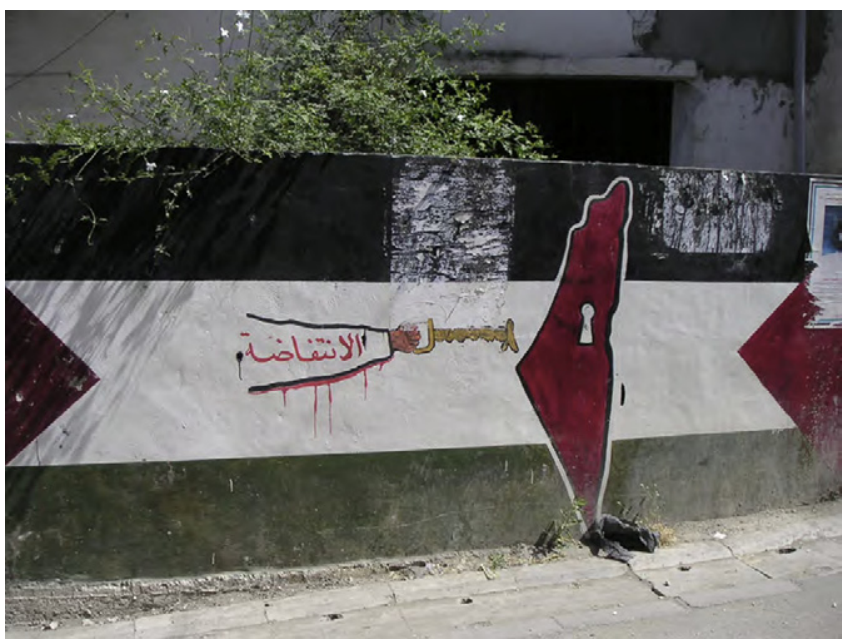

Fig. 8. Graffiti of the map of Palestine, Ein al-Hilwe Refugee Camp, Lebanon, 2005. Courtesy: Dr. Adam Ramadan.

and legitimacy; a return to a "normal" national political existence, where a cohesive nation resides within its homeland.

Like Israeli maps, Palestinian maps are used as devices of narrating Palestinian geography, history and cultural memory. Palestinian researchers, most notably Salman Abu-Sitta (2000) and Walid Khalidi (1992) documented the Palestinian landscape before 1948, collecting detailed information on the 400 villages destroyed or depopulated in the war. Their efforts resulted in a rich set of compendiums and maps, aimed to expand Palestinian knowledge of the lost homeland, educate the younger generations of Palestinians, and present the Palestinian case to international public opinion.

Even more than Israeli maps, the Palestine map is a performative statement of utopian vision. It is an idealised version of the historical homeland, seen through the nostalgia of loss and exile. The abstract, fetishised representation of the lost homeland stands at the core of Palestinian nationalist discourse, binding together its different and sometimes contradictory visions. Embedded in the map are a set of unresolved questions, not dissimilar to those facing Israelis: on relations between Palestinians in the West Bank and Gaza and other Palestinian communities, in Israel and the diaspora; on future relations with Israelis; and, perhaps most difficult, on the possible meanings of Palestinian Return within current political horizons.

\section{Dividing the map?}

Israeli-Palestinian peace talks, which have been taking place since the early 1990s, have aimed to resolve the conflict through territorial partition. In the two decades since, the "two-state solution" has been endorsed by an international consensus. The autonomous Palestinian Authority, established in 1993 as part of the Oslo accords, was considered a first step towards a Palestinian nation-state in the West Bank and Gaza, living peacefully alongside Israel. Advocates of this framework argued that the conflict could only be solved through territorial compromise. According to the international logic of nation-states, identifying nation, land and state as one unit, the national aspirations of both peoples would be re-charted onto their newly-defined borders. Anyone referring to Israel or Palestine would know clearly where one ended and the other began, at least in political terms. The "two-state solution" seemed an inevitable outcome to most observers including seasoned political geographers. Writing in the late 1990s, David Newman predicted that the "post-modern" map of the Oslo process, with its complicated regime of autonomous enclaves, was 
but a transitional stage, leading to Palestinian sovereign state (Newman, 1996). And yet this has not been the case. As of 2011, almost two decades after the Oslo agreement, the prospects of partition and the establishment of a viable Palestinian state are unclear. Repeated failure of negotiations, continued Israeli settlement in the West Bank, horrific violence and war, and the break up of the Palestinian Authority into two rival factions in the West Bank and in Gaza, all put the inevitably of a Palestinian state in severe doubt.

As I have shown, some have argued that this failure is rooted in the irreconcilable territorial ambitions of both sides, represented succinctly in their maps. However, if this was the case, and both sides were committed to maximalist visions of their homelands, there would be no room for negotiations to begin with. According to negotiators' accounts, differences on borders were less significant than the disagreement on the future of Jerusalem and the Palestinian refugees (Arieli, 2010). Most recently, Israeli demands for recognition as a "Jewish state" emerged as key obstacle in the negotiations. Palestinians rejected this demand as an attempt to undermine the status of Palestinian minority within Israel, and to invalidate Palestinian "Right of Return" (Zreik, 2011). All these are not territorial issues; rather, they touch on historical narrative, cultural memory, and the future character of Israel and Palestine. In the words of Palestinian journalist Rami Khouri (1996), the Palestinian-Israeli conflict is seemingly about land, and yet land captures the deeper issues and needs - concepts of identity, community, and nationhood, expressed through the modern vocabulary of sovereignty and statehood. As I have shown, these issues are performed visually through the mirror-maps of Israel and Palestine. At the end of the day, the overlapping maps present the difficulty in dividing Israel/Palestine, not because they are claims for complete territorial sovereignty, but because they represent a host of intractable issues left unaddressed by partition.

With the collapse of the Oslo process, scholars have called to see beyond the identity/territory/sovereignty matrix (Doumani, 2007). Following Arjun Appadurai's work on transnationalism, Dan Rabinowitz has argued that globalisation strengthens the "diasporic subjectivity" among Israelis and Palestinians and thus calls into question the viability of territorial nationalism as a framework to resolve the conflict. Much of Zionist and Palestinian nationalist discourses took shape outside the country, among diaspora and refugee communities, and this diasporic experience played a crucial role in the idealisation and the de-territorialisation of the homeland (Rabinowitz, 2000). An increasing number of scholars and activists, convinced that "the two-state solution" is no longer viable, called for a single bi-national state in Israel/Palestine (Abunimah, 2006; Benvenisti, 2010; Judt, 2003; Nusseibeh, 2011). This renewed interest in bi-nationalism does not stem out of a wishful desire for a post-nationalist world, or the perception of an immanent "death of the nation-state", but rather because of the utter failure of the nation-state discourse to disentangle the Israeli-Palestinian bi-national reality. Nonetheless, such ideas have remained insignificant politically. Bi-nationalism is considered highly undesirable by most observers in Israel/Palestine (Behar, 2011; Farsakh, 2011).

The persistence of the Israel/Palestine map as a site of identity and emotional appeal and as a site of accusations and counteraccusations, shows the strength of the "nation-state territorial epistemology" (Berking, 2006). Social science may have moved beyond the "territorial trap" (Agnew, 1994), yet the rhetoric of political maps, defining the nation in fixed and enclosed territorial units, remains the powerful prism through which global politics, and the Palestine/Israel conflict specifically, are perceived. Nonterritorial issues are being discussed, expressed and negotiated in territorial terms, resulting again and again in continuous failure.
Thus, the discussion of maps - and in general, of the role of space and geography in this conflict - is locked within a discourse that fails to account for itself.

\section{Critical cartography}

Faced with a seemingly irresolvable deadlock, this is the moment for scholarship to weigh in and suggest models of analysis that could overcome the impasse. The insights gained in critical scholarship of geography and cartography in recent decades appear especially pertinent. Much of this effort has been to explore the richness, heterogeneity and openness of space. Going beyond reified geographies defined through the territorial nation-state, geographers have put forward the notion of space as a juxtaposition of different narratives, and as fluid and dynamic rather than fixed and static (Massey, 2005, is but one prominent example in a citation list that could extend over pages). In critical cartography, the ontological status of the map has been critiqued thoroughly in various ways. Some have sought to strip the map from its scientific, objective and neutral guises, and show its inherent roots in power and ideology. Others emphasised the plurality of mapping practices through multiple and overlapping inscriptions, which are always open to flows, and have no unitary and fixed identity (Pickles, 2004). There is no single "correct use" of maps (Perkins, 2008) and even the same map yields alternative representations when used by different users (del Casino \& Hanna, 2005).

One of the most interesting concepts has been the model of space as palimpsest. While not new (Crang, 1998), the palimpsest model has become increasingly popular in recent years, also in Israel/Palestine. Unlike the political map and its exclusive portrayal of space from a single viewpoint, the palimpsest implies a simultaneity of multilayered perspectives. Space-text is constantly being re-written by numerous authors while its earlier texts are preserved, full with traces and erasures. Antropologist Susan Slyomovics described Israel/Palestine through Salman Rushdie's concept of "Palimpstine", a place where "worlds collide, flow in and out of one another, and washoff away" (Rushdie, 1995, quoted in Slyomovics, 1998: xxii). Palestinian social historian Musa Budairi has described Jerusalem as multiple overlapping cities, "Jerusalems" rather than a single Jerusalem, emphasising how different the city appears through the eyes of Arab Muslims compared with those of Orthodox Jews (Budairi, 1999). Grappling with the issue of conservation of Palestinian heritage in Tel Aviv, Israeli architects have suggested emphasising the many layers of the landscape, rather than focussing on a single meaning such as "Palestinian displacement" or "Zionist Revival" (Kashman, 2008). Their approach is reminiscent of Andreas Huyssen's interpretation of Berlin as "city-text", simultaneously vital, heterogeneous and ambivalent, a palimpsest which contains voids and illegibilities, but also offers the richness of memory and web of meanings (Huyssen, 2003).

The mirror-maps of Israel and Palestine form two such layers of the landscape-palimpsest. It is futile to ask which of these is true, as both of them represent a genuine perception: enacted through life stories, emotional attachment, histories and memories, the maps play a part in the lives of millions of people. The land between the Jordan River and the sea contains not one country but two (or indeed many more). This is a richness that could be appreciated rather than feared

How are we, therefore, to "accept" these two maps, and to reconcile their clashing trajectories? First, by stressing that difference is not the same as contradiction. Some scholars saw the different geographies of Palestine/Israel only in terms of exclusivist modern nationalism (Portugali, 1993; Wood, 2010), but distinct geographies of 
the Holy Land, Jewish, Muslim and others, have been in use centuries before their employment as territorial claims. The terms "Land of Israel" and "Palestine" go back to the early centuries of the first Millennium (Brawer, 1971; Mingantti, 1965), while the Zionist-Palestinian conflict is little older than a century. And while most of Israeli nomenclature was manufactured by naming committees, seeking to Judaise the landscape (Benvenisti, 2000), after decades in use, even this geography is no longer artificial, but rather very much a lived one through the experiences of millions of people.

In the Israeli-Palestinian context, acknowledging the validity of the other's geography requires more than a simple live-and-let-live approach. The conflict cannot be overcome simply by embracing tolerance and mutual recognition. Accepting the dual validity of the Israel/Palestine maps is difficult, exactly because one of the main practices of mapping has been to promote dispossession and denial. While the geographies of Israel and Palestine are not, in themselves, mutually exclusive, their function has been to exclude. The rigorous rewriting of the map by Zionist and Israeli cartographers, in order to obliterate Arab names and history, and the Palestinian reluctance to note the presence of Zionist settlements and towns, are not simply a matter of different viewpoints; they are also a matter of conscious political intention. In such an environment, maps are likely to be interpreted as territorial claims aiming "to wipe the other of the map". It is one thing to argue for the pluralist appreciation of geography in a North American context, for example in Pearce's (2008) map celebrating the voices of indigenous peoples. It is quite a different thing to argue for such an appreciation in a country still ravaged by war, military occupation and frequent attacks on civilians.

And yet, is there an alternative? Arguing for the richness of geography, and against exclusivists readings of maps, may be difficult and challenging. It may appear naive and idealist. But the failure of the Oslo process to divide the country into "Israel" and "Palestine" suggests that it is the territorial approach which has proven incredibly naive and impractical. The reductive approach to space and geography cannot work, even in the most pragmatic and realist terms.

\section{Conclusion}

Maps have proven an especially compelling rhetorical medium in the Israeli/Palestinian conflict. Both the Zionist/Israeli and the Palestinian national movement have employed cartographic language, resulting in mirror-maps, uncannily similar, championed from asymmetrical power positions. Following recent debates in critical cartography, my analysis has highlighted the non-territorial and performative aspects of these maps. Schoolchildren celebrating the maps in class, activists painting the map in graffiti, and the Palestinian leader Arafat shaping his headgear to look like Palestine, are all examples of bodily embodiments of mapping. These embodiments rely on a simple visual code that allows participants to recognise the map instantly. As an "empty signifier" at the heart of nationalist discourses, the map binds these performances together to a larger discursive formation, while leaving the meaning of the map itself open to interpretation. Emphasising the material and bodily enactments of mapping is crucial to understand the sacralisation of maps and the hold they have on popular imagination; it would be worthwhile to pursue similar investigations in other situations of acute political conflict, where maps are laden with emotional significance. The psychological effects of map-use should especially be noted; the uncanny effects of the "doubled" Israel/Palestine map, explains the strong reaction of Israelis and Palestinians to each other's maps. Psychoanalytical theory may be useful to understand the sense of attachment and rejection associated with maps. This aspect, which was only touched upon in this article, deserves a closer analysis from critical cartographers. Why do people feel so strongly about this means of geographical representation?

I have argued above that Israel/Palestine is unusual in that the same map is used to portray antagonistic political geographies. The patent overlap of the two maps invites a rethinking about maps beyond territoriality. Yet this approach could also be valid in other conflict situations, from Sri Lanka to the Basque Country, where oppositional maps appear to be calling for redrawing of borders, secession or unification. Are such territorialist interpretations valid in these cases, or should we read these maps also as performative instruments to convey emotional statements and claims about history and memory?

To understand the politically performative role of maps, scholars should pursue further a de-territorialised reading of maps. As my discussion of Israel/Palestine maps has shown, reading maps simply as territorial outlines of the national project overlooks their emotional and performative significance, as narratives of history, memory, and identity. For Israel, the map has served to prove its historical ties to the territory; by renaming mountains, rivers and sites, Zion was recreated and re-charted onto the landscape, displacing the Arab nomenclature. For Palestinians, the map has been a symbolic anchor for sustaining national solidarity in exile and under occupation; a means to preserve the memory of their destroyed homeland, and to defend their place in history. The maps, as representations of 1948 Palestine or the rediscovered ancient Zion, point to the utopian impulse that is central to Israeli and Palestinian nationalism, which, despite their differences, are both based on a political mythology of a "return to the land" (Peretz, 1993) and rely on diasporic imaginations. At the heart of the two national projects are a set of unresolved issues, to which a satisfying closure is impossible; the map, as a token of a mythical past and future, defers these issues and allows an escape from the present.

At the same time, as shown in my opening examples, there is no denial that Israel/Palestine maps have been repeatedly interpreted as territorial claims; this reading, indeed, is one of the key performances of mapping in this conflict. Such territorial interpretation, while reductive, is no doubt real and truthful in the sense that it is performed and debated in the public arena, reflecting the dominant logic of national territoriality in Israel/ Palestine and elsewhere.

Could the political map play a role in overcoming the territorial discourse with which it has been identified? Despite the vigorous scholarly discussion of the plurality of mapping uses, it seems that even leading critical geographers are doubtful that political maps can serve any role other than reactionary. Exasperated with the role of maps in the Dayton agreement to entrench exclusivist ethno-national territoriality in Bosnia, Jeremy Crampton called for "going beyond the map" (Crampton, 1996: 360). While Denis Wood, faced with he saw as "tit-for-tat" rhetoric of maps in Israel/ Palestine, imagined a world without maps - or rather, a world with a multiplicity of contradictory maps, so much that maps would lose all meaning. Without maps, he postulated, the nationstate would corrode and national identity would lose its significance (Wood, 2010).

However, the vast evocative appeal of maps in Israel/ Palestine mean that maps cannot be ignored or put aside. The potential, I believe, lies not in "going beyond the map", but rather in harnessing the map in new ways. As several geographers have suggested here (Herb et al., 2009) the response should not be to exasperate of maps, but rather to use maps creatively. The mirror-map of Israel/Palestine could become an uncanny starting point to discover the rich possibilities of shared geographies. 


\section{Acknowledgements}

I wish to thank Hannes Baumann, SOAS, London, Aryeh Amihay, Princeton University, Nur Bar-On, Hebrew University, Jerusalem, and Phoebe von Held, King's College, London, for discussing earlier drafts of this article and supplying me with useful comments. I would like also to thank the anonymous reviewers of the article for their thought-provoking comments and their intellectual engagement with my piece.

\section{References}

Abu-Sitta, S. H. (2000). The Palestinian Nakba 1948: The register of depopulated localities in Palestine (2nd ed.). London: Palestinian Return Centre.

Abunimah, A. (2006). One country: A bold proposal to end the Israeli-Palestinian impasse. New York: Metropolitan Books.

Aburish, S. (1998). Arafat from defender to dictator. London: Bloomsbury.

Agnew, J. (1994). The territorial trap: the geographical assumptions of international relations theory. Review of International Political Economy, 1, 53-80.

Aitken, S., \& Craine, J. (February 7 2006). Affective geovisualizations. Directions: A Magazine for GIS Professionals, 4(1). http://www.directionsmag.com/articles/ guest-editorial-affective-geovisualizations/123211.

Anderson, B. (1991). Imagined communities: Reflections on the origin and spread of nationalism (rev. ed.). London: Verso.

Arieli, S. (2010). People and borders: About the Israeli Palestinian conflict.

Bar-Gal, Y. (1991). The good and the bad: A hundred years of Zionist images in geography textbooks. London: University of London.

Bar-Gal, Y. (2003). Propaganda and Zionist education: The Jewish national fund, 1924-1947. Rochester: University of Rochester Press.

BBC. (2009). Israel admits tube advert map 'mistake'. http://news.bbc.co.uk/1/hi/ world/middle_east/8063435.stm Accessed 24.06.10.

Behar, Moshe (2011). Unparallel universes: Iran and Israel's one-state solution. Global Society, 25(3), 353-376.

Benvenisti, M. (2000). Sacred landscape: The buried history of the Holy Land since 1948. Berkeley: University of California Press.

Benvenisti, M. (28 January 2010). United we stand. Ha'aretz.

Berking, H. (2006). Contested places and the politics of space. In H. Berking, S. Frank, L. Frers, M. Löw, L. Meier, S. Steets, \& S. Stoetzer (Eds.), Negotiating urban conflicts: Interaction, space and control (pp. 29-39). London: Transaction Publishers.

Biggs, M. (1999). Putting the state on the map: cartography, territory, and European State formation. Comparative Studies in Society and History, 41, 374-411.

Billig, M. (1995). Banal nationalism. London: Sage.

Black, J. (1997). Maps and politics. London: Reaktion.

Bowker, R. (2003). Palestinian refugees: Mythology, identity, and the search for peace. London: Lynne Rienner Publishers.

Brawer, A. J. (1971). Land of Israel: geographical survey, names. In C. Roth, \& G. Wigoder (Eds.), Judaica (pp. 108-112). Jerusalem: Keter.

Brown, N. J. (2001). Democracy, history, and the contest over the Palestinian curriculum. Paper presented at the Adam Institute for Democracy and Peace, Jerusalem.

Budairi, M. (1999). Appendix I. In S. Tamari (Ed.), Jerusalem 1948: The Arab neighbourhoods and their fate in the war. Jerusalem: Institute of Jerusalem Studies.

del Casino, V. J. D., \& Hanna, S. P. (2005). Beyond the 'binaries': A methodological intervention for interrogating maps as representational practices. ACME: An International E-Journal for Critical Geographies, 4, 34-56.

Castel-Bloom, O. (1997). Dolly city. London: Loki Books.

Crampton, J. (1996). Bordering on Bosnia. GeoJournal, 39, 353-361.

Crampton, J., \& Krygier, J. (2006). An introduction to critical cartography. ACME: An International E-Journal for Critical Geographies, 4, 11-33.

Crang, M. (1998). Cultural geography. London: Routledge.

Dodge, M., Kitchin, R., \& Perkins, C. R. (2009). Thinking about maps. In M. Dodge, R. Kitchin, \& C. R. Perkins (Eds.), Rethinking maps: New frontiers in cartographic theory (pp. 1-25). New York: Routledge.

Doumani, B. (2007). Palestine versus the Palestinians? The iron laws and ironies of a people denied. Journal of Palestine Studies, 36, 49-64.

Fall, J. J. (2010). Artificial states? On the enduring geographical myth of natural borders. Political Geography, 29, 140-147.

Farsakh, Leila (2011). The one-state solution and the Israeli-Palestinian conflict: Palestinian challenges and prospects. The Middle East Journal, 65(1), 55-71.

Fortna, B. C. (2005). Change in the school maps of the late Ottoman Empire. Imago Mundi: The International Journal for the History of Cartography, 57, 23-34.

Freud, S. (2003). The uncanny. New York: Penguin.

Gavish, D. (2005). A survey of Palestine under the British Mandate, 1920-1948. London: Routledge.

Granot, O., \& Grossman, H. (2008). On the map. Jerusalem: Israel Museum.

Harley, J. B. (1989). Deconstructing the map. Cartographica, 26, 1-20.

Herb, G., Häkli, J., Corson, M., Mellow, N., Cobarrubias, S., \& Casas-Cortes, M. (2009). Intervention: mapping is critical! Political Geography, 28, 332-342.

Huyssen, A. (2003). Present pasts: Urban palimpsests and the politics of memory. Stanford: Stanford University Press.
Israel Ministry of Foreign Affairs. (2008). Israel's story in maps. http://www.mfa.gov. il/MFA/Facts+About+Israel/Israel+in+Maps/ Accessed 20.06.10.

Judt, T. (2003). Israel: The alternative. The New York Review of Books.

Kadman, N. (2008). Erased from space and consciousness: Depopulated Palestinian villages in the Israeli-Zionist discourse. Jerusalem: November Books.

Kashman. (2008). Absent conservers, the future of the "Bayyarat" of Jaffa. http://www. bateibeer.com/article.html Accessed 20.06.11.

Khalidi, W. (1992). All that remains: The Palestinian villages occupied and depopulated by Israel in 1948. Washington, D.C.: Institute for Palestine Studies.

Khalili, L. (2007). Heroes and martyrs of Palestine: The politics of national commemoration. Leiden: Cambridge University Press.

Khouri, R. (1996). Forward. In D. Arzt (Ed.), Refugees into citizens: Palestinians and the end of the Arab Israeli conflict. New York: Council on Foreign Relations.

Kitchin, R., \& Dodge, M. (2007). Rethinking maps. Progress in Human Geography, 31 $331-344$.

Kuttab, D. (2010). Israeli tourism maps annex Palestinian lands and omit Palestinian cities. http://www.huffingtonpost.com/daoud-kuttab/israeli-tourism-mapsanne_b_556339.html Accessed 24.06.10.

Kwan, M.-P. (2007). Affecting geospatial technologies: toward a feminist politics of emotion. The Professional Geographer, 59, 22-34.

Laclau, E. (2007). Emancipation(s). London: Verso.

Massey, D. (2005). For space. London: Sage.

Meridor, N. (2006). An examination of Palestinian fifth and tenth-grade textbooks for the 2004-2005 school year. The Intelligence and Terrorism Information Center. www.terrorism-info.org.il/malam_multimedia/english/eng./as_nm_e. pdf Accessed 30.06.11.

Mingantti, P. (1965). Filastin. In P. Bearman, T. Bianquis, C. Bosworth, E. van Donzel, \& W. Heinrichs (Eds.), Encyclopedia of Islam (2nd ed.). Leiden: Brill.

Mogel, L., \& Bhagat, A. (Eds.). (2008). An atlas of radical cartography. Los Angeles: Journal of Aesthetics \& Protest Press.

Mohr, R. (2006). Territory, landscape and law in three images of the Basque Country. In W. Taylor (Ed.), The geography of law: Landscape, identity and regulation. Hart: Oxford.

Monmonier, M. S. (1996). How to lie with maps (2nd ed.). Chicago: University of Chicago Press.

Moscrop, J. J. (2000). Measuring Jerusalem: The Palestine exploration fund and British interests in the Holy Land. London; New York: Leicester University Press.

Newman, D. (1996). Shared spaces - separate spaces: the Israel-Palestine peace process. GeoJournal, 39, 363-375.

Nusseibeh, S. (2011). The question of Palestine. Harvard: Harvard University Press.

Paasi, A. (1996). Territories, boundaries, and consciousness: the changing geographies of the Finnish-Russian boundary. Chichester: J. Wiley \& Sons.

Paasi, A. (1999). The changing pedagogies of space: representation of the other in Finnish school geography textbooks. In A. Buttimer, S. Brunn, \& U. Wardenga (Eds.), Text and image: Social construction of regional knowledges (pp. 226-237). Leipzig: Institut für Länderkunde.

Palestine Solidarity Campaign. (2009). VICTORY! Israeli tourism posters removed from London underground!. http://www.palestinecampaign.org/index7b.asp? $\mathrm{m} \_\mathrm{id}=1 \& 11 \_\mathrm{id}=4 \& 12 \_\mathrm{id}=24 \&$ Content_ID=644 Accessed 24.06.10.

Pearce, M. W. (2008). Framing the days: place and narrative in cartography Cartography and Geographic Information Science, 35, 17-32.

Peled-Elhanan, N. (2008). The denial of Palestinian national and territorial identity in Israeli schoolbooks of history and geography 1996-2003. In R. Dolón, \& J. Todolí (Eds.), Analysing identities in discourse: Discourse approaches to politics, society and culture. Philadelphia: J. Benjamins.

Peretz, D. (1993). Palestinians, refugees, and the Middle East peace process. Washington, D.C: United States Institute of Peace Press.

Perkins, C. R. (2008). Cultures of map use. The Cartographic Journal, 45, 150-158.

Pickles, J. (2004). A history of spaces: Cartographic reason, mapping, and the geocoded world. London: Routledge.

Pina, A. D. (2005). Palestinian education and the debate over textbooks. Washington D.C.: L.O.C. Congressional Research Service.

PMW. (2007). Senator Clinton condemns Palestinian textbook bias. http://www. palwatch.org/main.aspx?fi=91\&doc_id=1949 Accessed 21.06.10.

Portugali, J. (1993). Implicate relations: Society and space in the Israeli-Palestinian conflict. Boston: Kluwer Academic Publishers.

Rabinowitz, D. (2000). Postnational Palestine/Israel? Globalization, diaspora, transnationalism, and the Israeli-Palestinian conflict. Critical Inquiry, 26, 757-772.

Radcliffe, S. A., \& Westwood, S. (1996). Remaking the nation: Place, identity and politics in Latin America. New York: Routledge.

Ramadan, A. (2009). A refugee landscape: writing Palestinian nationalisms in Lebanon. ACME: An International E-Journal for Critical Geographies, 8, 69-99.

Rogoff, I. (2000). Terra infirma: Geography's visual culture. London: Routledge.

Rushdie, S. (1995). The Moor's last sigh. London: J. Cape.

Said, E. (1994). The politics of dispossession: The struggle for Palestinian self-determination. London: Chatto \& Windus.

Sanbar, E. (2001). Out of place, out of time. Mediterranean Historical Review, 16, 87-94.

Sayigh, Y. Y. (1997). Armed struggle and the search for state: The Palestinian national movement, 1949-1993. Oxford: Oxford University Press.

Shaath, N. A., \& Mikdashi, H. (1981). Palestine: Stamps (1865-1981). Beirut: Dar alFata al-Arabi.

Slyomovics, S. (1998). The object of memory: Arab and Jew narrate the Palestinian village. Philadelphia: University of Pennsylvania Press.

Sorek, T. (2004). The orange and the 'cross in the crescent': imagining Palestine in 1929. Nations and Nationalism, 10, 269-291. 
Sparke, M. (2005). In the space of theory: Postfoundational geographies of the nationstate. Minneapolis: University of Minnesota Press.

Starr, D. A. (2000). Reterritorializing the dream: Orly Castel-Bloom's remapping of Israel identity. In L. J. Silberstein (Ed.), Mapping Jewish identities. New York Univresity.

Steele, J. (2006). Lost in translation, The Guardian, Comment is Free. Available at: http://www.guardian.co.uk/commentisfree/2006/jun/14/post155 [Accessed August 2, 2011].

Tibawi, A. L. (1963). Visions of the return: the Palestine Arab refugees in Arabic poetry and art. The Middle East Journal, 17, 507-526.

Webster, D. (2001). "Already sovereign as a people": A foundational moment in West Papuan nationalism. Pacific Affairs, 74, 507-528. whatreallyhappened.com. The maps tell the true story. http://whatreallyhappened. com/WRHARTICLES/mapstellstory.html Accessed 20.06.10.

Winichakul, T. (1994). Siam mapped: A history of the geo-body of a nation. Honolulu: University of Hawaii Press.

Wolinetz, H. (1975). Arab Philatelic propaganda against the State of Israel. Ann Arbor: H. D. Wolinetz.

Wood, D. (2010). Rethinking the power of maps. New York: Guilford Press.

Wood, D., \& Fels, J. (2008). The natures of maps: Cartographic constructions of the natural world. Chicago: University of Chicago Press.

Zreik, Raef (2011). Why the Jewish state now? Journal of Palestine Studies, 40(3), 23-37. 